\title{
COMPARATIVE STUDY OF TRANSVERSE PREPUTIAL ONLAY ISLAND FLAP VS TUBULARISED ISLAND FLAP URETHROPLASTY
}

\author{
Jayapal Kommaㄹ, Vinodh Kumar Talari², Mandakini Talapaneni Kotaiah³, Kumba Nagarjuna ${ }^{4}$ \\ ${ }_{1}^{1}$ Assistant Professor, Department of Paediatric Surgery, Guntur General Hospital, Guntur, Andhra Pradesh. \\ ${ }^{2}$ Assistant Professor, Department of Paediatric Surgery, Sri Venkateswara Medical College, Tirupathi, Andhra Pradesh. \\ ${ }^{3}$ Assistant Professor, Department of Paediatric Surgery, Niloufer Hospital for Women and Children, Hyderabad, Telangana. \\ ${ }^{4}$ Professor and HOD, Department of Paediatric Surgery, Gandhi Medical College, Secunderabad, Telangana.
}

\section{ABSTRACT}

\section{BACKGROUND}

Aims and Objectives- To study and compare the outcome of Onlay Preputial Island Flap (OIF) and Tubularised preputial Island Flap (TIF) urethroplasty in children with hypospadias.

\section{MATERIALS AND METHODS}

Observational comparative study conducted between August 2004 and January 2007; 45 children with hypospadias underwent single stage urethroplasty, 27 children without chordee underwent OIF and 18 with chordee underwent TIF. The outcome and complications were noted and compared.

\section{RESULTS}

Complications were seen in 7 children of OIF group (25.9\%) and 8 children of TIF group (44.4\%). The overall commonest complication was Urethrocutaneous Fistula (UCF). Fistula rates were higher in the OIF group (22.2\%), whereas strictures were only seen in the TIF group (22.2\%). There was one flap necrosis in the TIF group (5.5\%).

\section{CONCLUSION}

OIF and TIF are popular single stage procedures and are reliable techniques in hypospadias repair. In our prospective observational study, OIF had low complication rate when compared to TIF. UCFs were seen in the OIF group and stricture in the TIF group.

\section{KEYWORDS}

Onlay Preputial Island Flap (OIF), Tubularised Preputial Island Flap (TIF), Urethrocutaneous Fistula (UCF).

HOW TO CITE THIS ARTICLE: Komma J, Talari VK, Kotaiah MT, et al. Comparative study of transverse preputial onlay island flap vs tubularised island flap urethroplasty. J. Evolution Med. Dent. Sci. 2017;6(35):2903-2908, DOI: 10.14260/Jemds/2017/626

\section{BACKGROUND}

The term hypospadias is derived from the Greek "Hypo" means under and "spadon" means a rent or a fissure. Hypospadias is a common paediatric urological condition with an incidence of 3.2 per 1000 live births. It is an arrest in the normal development of the urethra, foreskin and ventral aspect of penis producing a functioning phallus that allows a boy to void as a "pointer" instead of a "squatter" and later becomes a sexually active adult elevates the surgeon to the ranks of the divine. The principles of repair involve straightening of penis (Orthoplasty), creating a slit-like meatus at the tip of the penis (Urethroplasty and meatoplasty) and proper skin coverage.

Around 300 procedures are described to repair hypospadias. The presence of chordee alters our management with respect to choice of surgical repair. Three distinct pathologic types of chordee have been described by

Financial or Other, Competing Interest: None.

Submission 20-03-2017, Peer Review 23-04-2017,

Acceptance 26-04-2017, Published 01-05-2017.

Corresponding Author:

Dr. Jayapal Komma,

Door \# 4-15-72/1, Postal Colony,

Amaravathi Road,

Guntur-522002,

Andhra Pradesh.

E-mail: jayapalkomma@rediffmail.com

DOI: $10.14260 /$ jemds $/ 2017 / 626$
Horton and Devine in $1973 .{ }^{1}$ In the first, the spongiosum is absent in the distal penis, an abnormal fibrous layer prevents the penis from being straight and the urethra is often paper thin. In the second type the urethra is completely developed, but the Buck's fascia and the Dartos fascia is abnormal. The third type is described as the skin chordee and is due to abnormality of the superficial Dartos fascia. A fourth type has been described by Kramer et al in 1982, which may be the result of disproportional growth of the dorsal portion of the corporal bodies causing downward deflection. Significant chordee is clinically defined as curvature greater than $20^{\circ}$.

The other important factor is the presence or absence of urethral plate after adequate chordee correction, which will determine the choice of repair.,2,3,4 If the urethral plate is present, the quality of the urethral plate will help us decide regarding the procedure. In the presence of a good mucosa lined, urethral plate tubularisation incised plate urethroplasty can be performed. If the urethral plate is fair with no chordee or after chordee correction, the choice would be an onlay flap urethroplasty. If the cause of chordee is at the level of Buck's or Dartos fascia, the urethral plate has to be excised which will mandate a tubularised flap urethroplasty.

An understanding of the vascular anatomy of hypospadias, avoiding entry into the dorsal pedicle or the spongiosum ventrally will make for a haemostatic procedure with minimal blood loss. With meticulous attention to 
dissection, there can be consistent preservation of the spongiosum, which can then be incorporated into the repair. Leaving the spongiosum maximally inserted into the tunica albuginea avoids injury to the delicate vascular structure. The spongiosal support contributes to a lower complication rate, particularly the fistula rate. For these reasons, island flap urethroplasty is a good procedure of choice.

Transverse island flaps of inner preputial skin have provided a reliable technique for the repair of hypospadias, especially proximal hypospadias. ${ }^{5}$ These flaps can be used as a single stage procedure minimising multiple hospital admissions if devoid of complications. We compare Onlay Island Flap vs Tubularised Island Flap urethroplasty.

\section{Aims and Objectives}

To compare the outcome and the complication rate in children who underwent Onlay Preputial Island Flap Urethroplasty and Tubularised Preputial Island Flap Urethroplasty.

\section{MATERIALS AND METHODS}

It is an observational comparative study conducted in Department of Paediatric Surgery between August 2004 and January 2007. Our spectrum included children presenting first time with hypospadias ranging from mid-penile, proximal penile, penoscrotal to scrotal hypospadias. All distal penile and perineal hypospadias and children with associated disorder of sexual differentiation were excluded from this study.

45 consecutive children who presented to the outpatient department with mid-penile, proximal penile, penoscrotal or scrotal hypospadias in the given period were included in the study. The age ranged between 1 to 12 years with the average age being 5 years; 28 children belonged to the 1 to 5 years' age group, whereas 17 belonged to the 6 to 12 years' age group. The procedure was decided depending on the presence or absence of chordee after degloving of penis. Of the 45, 27 children had no chordee after degloving and underwent Onlay Island Flap urethroplasty and 18 children required excision of urethral plate to correct chordee and underwent Tubularised Island Flap urethroplasty. None of them received testosterone injections or creams preemptively. Informed consent was taken from all patients' guardians.

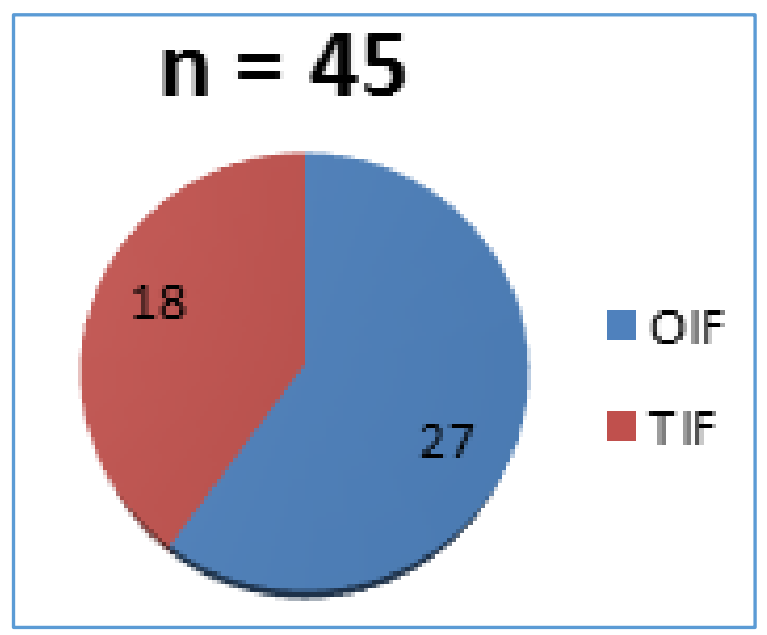

Out of 45, 36 had chordee. Mild chordee was where the ventral curvature was less than $20^{\circ}$, moderate was between $20^{\circ}$ to $50^{\circ}$ and severe chordee was more than $50^{\circ}$. Mild chordee was seen in 17 cases, of which all of them had mid penile hypospadias. Moderate chordee was seen in 11 children, majority of them having proximal penile and severe in 8 children seen in some proximal penile, all penoscrotal and scrotal hypospadias.

\begin{tabular}{|c|c|c|}
\hline Sl. No. & Type of Chordee & No. of Cases \\
\hline 1 & Mild $\left(<20^{\circ}\right)$ & 17 \\
\hline 2 & Moderate $\left(20^{\circ}\right.$ to $\left.50^{\circ}\right)$ & 11 \\
\hline 3 & Severe $\left(>50^{\circ}\right)$ & 8 \\
\hline
\end{tabular}

Pre-operatively, children were given enemas the previous night and a betadine scrub bath on the day of surgery. Broad spectrum antibiotic injection Cefotaxime was given intravenously in a dose of $50 \mathrm{mg} / \mathrm{kg} /$ dose at the time of induction of anaesthesia. General anaesthesia and regional anaesthesia in the form of caudal anaesthesia was given.

The operating time ranged between 1 to $1 \frac{1}{2}$ hours. Bipolar cautery was used. Initial steps of both the procedures included degloving the penile shaft, excising the tethered tissue lateral to the urethral plate or excising the urethral plate till the chordee was corrected, which was confirmed by the Gittes Stoke's manoeuvre. ${ }^{6}$ For haemostasis in the initial part of the procedure, gauze soaked in 1 in 1,00,000 dilution adrenaline was used. After correction of chordee, tourniquet was placed at the root of the penis and time was noted. Adequate glans wings were raised. After chordee correction depending on the presence of urethral plate Onlay Island Flap urethroplasty was performed. If chordee was severe and urethral plate had to be excised, Tubularised Island Flap urethroplasty was performed. We did not use loupes. The suture material we used was 5-0 vicryl ${ }^{7}$ with round body or cutting needle and urethroplasty was performed over a 7 to 9-Fr infant feeding tube. An adequate wide transverse inner preputial, preferably trapezoid was taken as the flap and was raised on the vascular pedicle taking care not to damage the vascularity up to the base or root of penis. On lap flap, we used continuous sutures on either sides of the vertical aspect. Interrupted sutures were used between the native urethra and neourethra and at the glans. In Tubularised flap urethroplasty, a tube was created over a 10-Fr infant feeding tube with continuous 5-0 Vicryl sutures and the wide trapezoid end sutured to the native urethra in an oblique fashion to avoid stricture. Adequate mobilisation of the glans wings was done and the glans was wrapped over the terminal part of neourethra after replacing the 10 -Fr with a $7-9-\mathrm{Fr}$ infant feeding tube. Adequate neourethral cover was done either by raising Byars' flaps or by Z-plasty. Dressing was done with a betadine soaked gauze and compressive dressing with Dynaplast was applied. We did not perform suprapubic cystostomy in any of these children.

Post-operatively, all children were hydrated well and catheters flushed as and when needed to prevent blocking of catheters. They received stool softeners to avoid straining, while passing stools which can cause slippage of catheter. Intravenous antibiotics were given for 10 days till catheter removal. Anticholinergics in the form of Tab. Oxybutynin at a 
dose of $0.2 \mathrm{mg} / \mathrm{kg} /$ dose was given twice daily to prevent bladder spasms. Dressing was changed under sedation on $5^{\text {th }}$ postoperative day and catheter was removed on $10^{\text {th }}$ postoperative day. Post-operative stream was noted and complications like flap necrosis, urethrocutaneous fistula, meatal stenosis, stricture, recurrent chordee and penile torsion were documented. Post catheter removal, children were advised sitz bath with topical ointment for 2 weeks. They were also given a week's course of oral antibiotics in the form of Cephalexin at $15 \mathrm{mg} / \mathrm{kg} / \mathrm{dose}$ three times a day.

\section{RESULTS}

Intraoperatively, all children did well. Post-operatively, none of the children had wound infection or catheter related issues like blockage of catheter or accidental slippage.

All the patients were followed for at least 12 months, initially 2 weeks, 6 months and 12 months postoperatively. 28 children were of the 1 - 5 years' age group, of which 18 underwent OIF and 10 underwent TIF. In our series, midpenile hypospadias was the commonest $(19 / 45)$ followed by proximal penile $(15 / 45)$, penoscrotal $(10 / 45)$ and one scrotal hypospadias. Rest 17 were between $6-12$ years' age group, among which 10 underwent OIF and 7 underwent TIF.

\begin{tabular}{|c|c|c|}
\hline Patients & $\begin{array}{c}\text { Onlay Island } \\
\text { Flap } \\
\text { No = 28 }\end{array}$ & $\begin{array}{c}\text { Tubularised Island } \\
\text { Flap } \\
\text { No }=\mathbf{1 7}\end{array}$ \\
\hline Age (Years) & 18 & 10 \\
$1-5$ & 10 & 7 \\
$6-12$ & 18 \\
\hline
\end{tabular}

\begin{tabular}{|c|c|c|}
\hline Sl. No. & Position of Meatus & No. of Cases \\
\hline 1 & Mid Penile & 19 \\
\hline 2 & Proximal Penile & 15 \\
\hline 3 & Penoscrotal & 10 \\
\hline 4 & Scrotal & 1 \\
\hline & Total & $\mathbf{4 5}$ \\
\hline
\end{tabular}

\begin{tabular}{|c|c|c|}
\hline $\begin{array}{c}\text { Post Chordee } \\
\text { Correction Meatal } \\
\text { Position }\end{array}$ & $\begin{array}{c}\text { Onlay Island } \\
\text { Flap No= 27 }\end{array}$ & $\begin{array}{c}\text { Tubularised Island } \\
\text { Flap } \\
\text { No = 18 }\end{array}$ \\
\hline Mid penile & 19 & 0 \\
Proximal penile & 8 & 7 \\
Penoscrotal & 0 & 10 \\
Scrotal & 0 & 1 \\
\hline
\end{tabular}

All the mid penile hypospadias 19,8 proximal penile hypospadias underwent only island flap urethroplasty, whereas 7 proximal penile, all penoscrotal (10) and 1 scrotal hypospadias underwent tubularised island flap urethroplasty.

TIF had a higher complication rate (44.4\%) when compared to OIF (25.9\%).

Overall, urethrocutaneous fistula was the commonest complication. 6 children who underwent OIF and 3 who underwent TIF had urethrocutaneous fistula.

All the UCFs were at the junction between native urethra and neourethra. Strictures were seen in 4 children, all who underwent TIF between the native urethra and neourethra junction. One child who underwent TIF was an older child, 12 years of age, had flap necrosis. One 5-year-old child, preoperatively had $115^{\circ}$ torsion to the left, post-surgery he had residual torsion of $20^{\circ}$ to the left.

\begin{tabular}{|c|c|c|}
\hline Complications & $\begin{array}{c}\text { Onlay Island } \\
\text { Flap (27) } \\
\text { No (\%) }\end{array}$ & $\begin{array}{c}\text { Tubularised } \\
\text { Island Flap (18) } \\
\text { No (\%) }\end{array}$ \\
\hline Fistula & $6(22.2)$ & $3(16.6)$ \\
Stricture & 0 & $4(22.2)$ \\
Flap Necrosis & 0 & $1(5.5)$ \\
Torsion & $1(3.7)$ & 0 \\
Recurrent Chordee & 0 & 0 \\
Megalourethra & 0 & 0 \\
Overall & $7(25.9)$ & $8(44.4)$ \\
\hline
\end{tabular}

All UCFs underwent fistula repair 6 months post primary surgery and are doing fine. Among the 4 children who had stricture, 3 were amenable to urethral dilatation and responded well. Urethral dilatation was done under anaesthesia at a period of 2 weeks post-operatively and as necessary 2 children needed 2 dilatations set 2 weeks apart, whereas one child needed dilatation 3 times with a 2 -week interval between each dilatation. One child had acute retention of urine secondary to a tight stricture for which urethrotomy was done followed by redo-urethroplasty at a later date. There were no meatal stenosis, megalourethra or diverticula noted in any of these children. No recurrent chordee was seen either. The $p$ value calculated for results was by chi square test, which was 1.667 signifying similar outcomes and complication rate in either of the groups. There was no statistical significance in either of the groups.

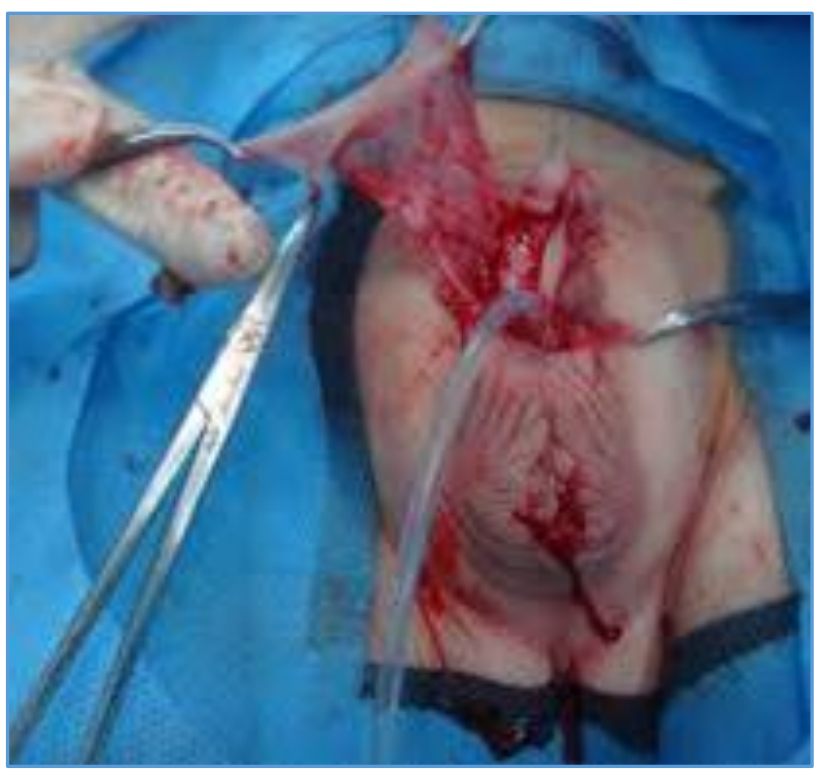

Onlay Island Flap 


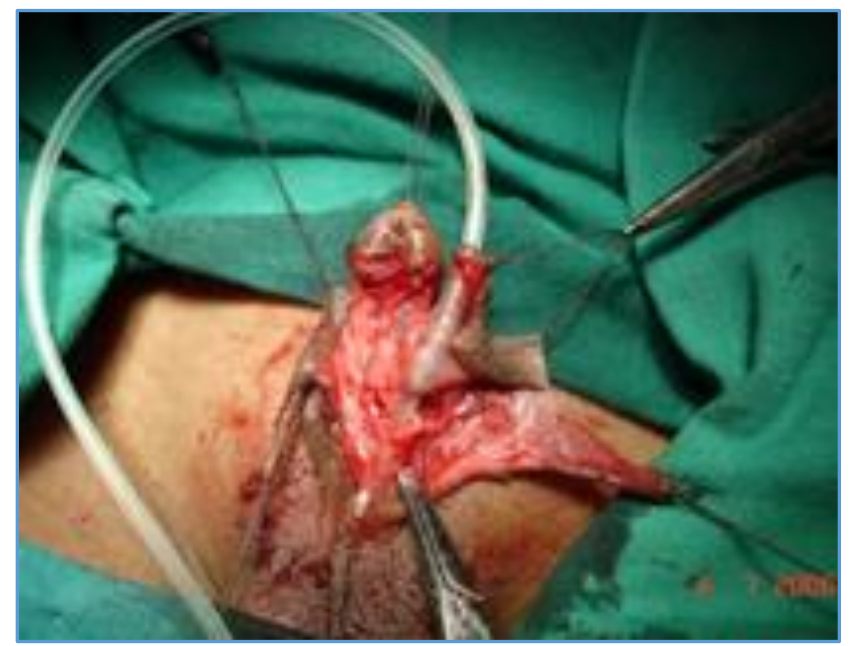

Tubularised Island Flap

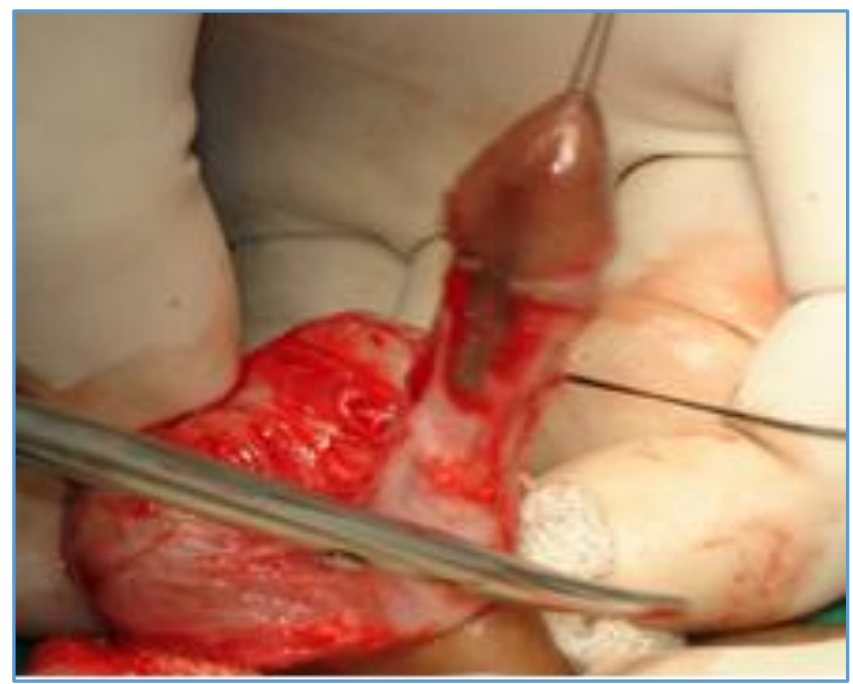

After Degloving on Penis with Urethral Plate Intact for Onlay

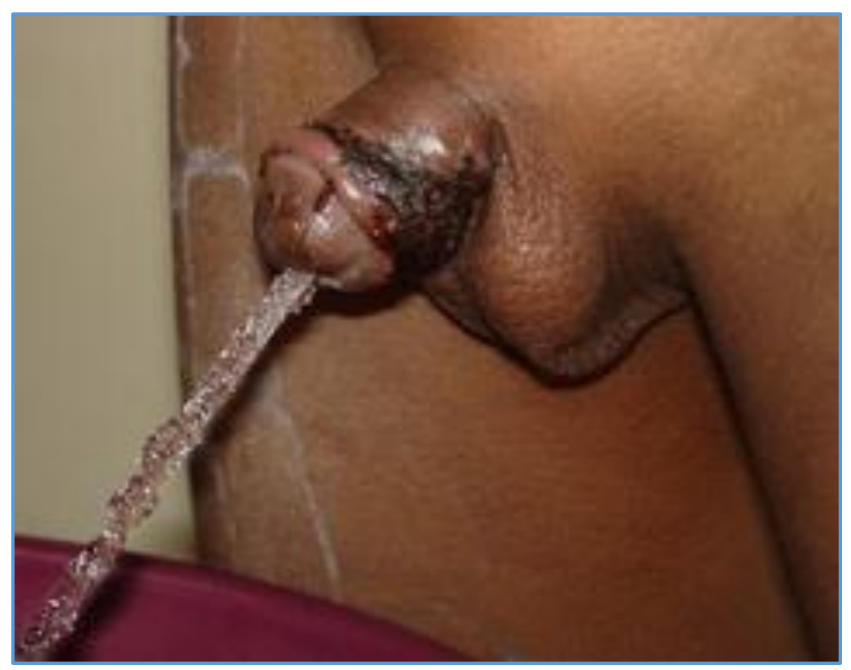

Post OIF Stream

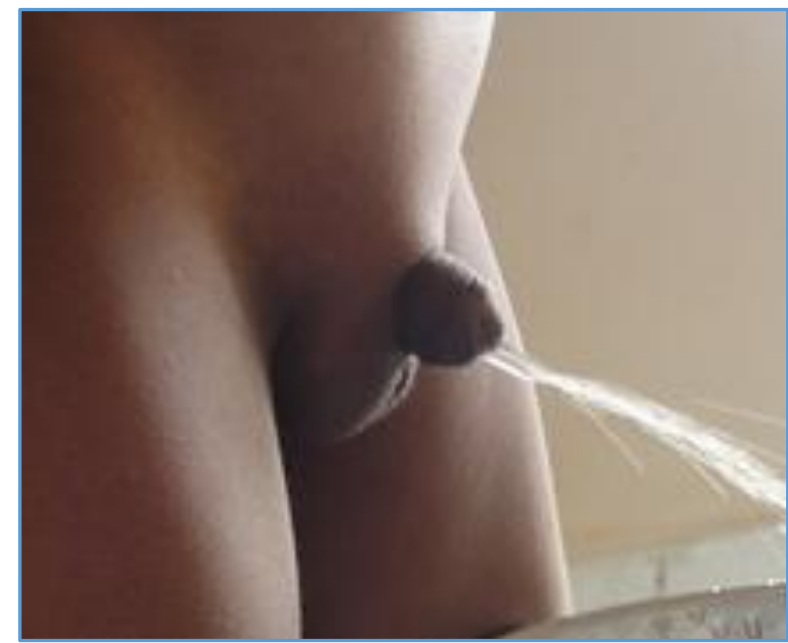

Post TIF Stream

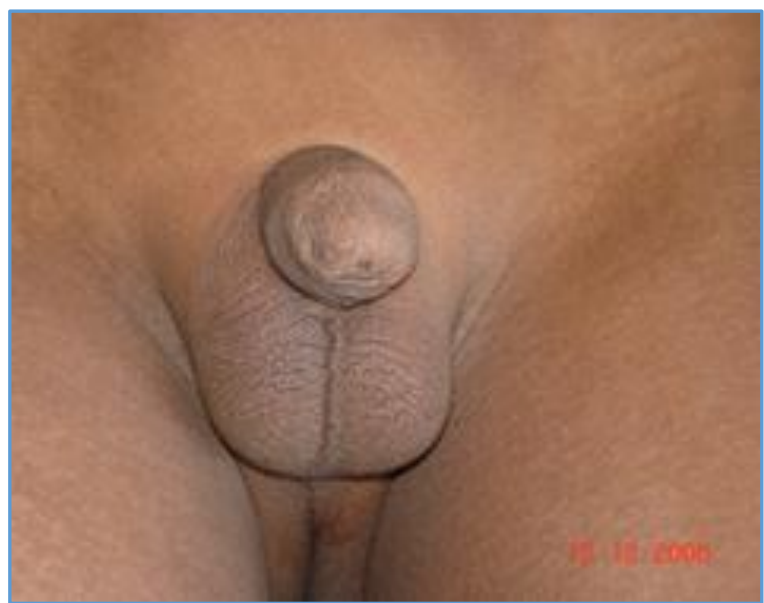

Post-Op Cosmesis

\section{DISCUSSION}

Most of the hypospadias regardless of severity are associated with a prepuce that could be sufficient to create a neourethra to bridge the existing gap and cover the repair with skin. Success depends on-

- The inner layer of prepuce has to be long enough.

- The epithelial surface of the prepuce has to be adequate.

- The subcutaneous tissue between the outer and inner layer of prepuce has to be sufficient and carry enough blood vessels for vascularisation of the two layers.

However, any technique using the prepuce for the repair jeopardises the blood supply, endangering the result. Knowing the blood supply of the prepuce is essential, so that preservation of the preputial vascularisation is not merely fortuitous. One should be aware of the normal vascularisation of the prepuce. Although, it is very difficult to identify individual variations, especially during surgery it is of great importance to look for them. These vessels can then be used individually, selectively or collectively according to the anatomical variation present in the choice of flap to be performed. In the majority of cases, the desired success should be guaranteed. 
OIF and TIF are well tested and tried techniques among the 300 odd procedures described for hypospadias. We were able to achieve good cosmetic and functional result in both the groups. Good cosmesis was based on a circumcised appearance wherein the penis was straight with no chordee, meatus was at the tip of the glans, there was no bulk of tissue noted on the ventral aspect and with acceptable torsion in one case. Overall complication rate with OIF was $25.9 \%$ when compared to TIF, which was $44.4 \%$. This is similar to the study by Demirbilek $\mathrm{S}^{8}$ et al, $33 \%$ with OIF and $38 \%$ with TIF.

Although, Duckett ${ }^{5}$ reported a complication rate of $7.5 \%$, subsequent studies showed higher post-operative complications of single stage tubularised urethroplasty with the rate varying from 8.6 to $56 \% .{ }^{9-13}$ Urethrocutaneous fistula rate was $22 \%$ with $\mathrm{OIF}$ and $16.6 \%$ with TIF, which was quite similar to that reported by Monfort ${ }^{14}$ et al and Jayanthi ${ }^{15}$ et al (20\%) and Dewan ${ }^{16}$ et al (34\%). Wiener ${ }^{2}$ et al compared outcomes following OIF and TIF in 132 patients and had a fistula rate of $14 \%$ and $17 \%$ respectively, but noted larger fistulas requiring more complex repairs in the island tube group. Baskin ${ }^{17}$ et al reported similar fistula rate $10 \%$ (OIF) and $15 \%$ (TIF) and postulated that the lower fistula rate for the OIF maybe a result of improved healing of the repair with preservation of the spongiosa supported urethral plate.

Strictures were only seen in those who underwent TIF (22\%) as opposed to Castanon ${ }^{18}$ et al who had $7.1 \%$ and Elbakry ${ }^{19}$ A who had 9\%.

We had 1 (5.5\%) flap necrosis as opposed to $7 \%$ by a study conducted by Elbakry A.

In another study conducted by Hayashi $\mathrm{Y}^{19}$ et al, one UCF developed out of 13 patients who underwent TIF urethroplasty. The overall complication rates were $12 \%$ in a study conducted by Piro Bisca $\mathrm{C}^{20}$ et al. The overall complication rate was $6 \%$ in OIF technique in a study by Gearhart JP and Borland RN. ${ }^{21}$ The cause of stricture is related to circular anastomosis between urethra and flap. This type of anastomosis is not performed in the onlay repair. From a patient's perspective, fistula is rather a less unpleasant complication than a stricture and argument in favour of OIF repair. Analysis of type of technique used regarding the initial meatal position shows that the TIF was performed in patients with most severe hypospadias.

\section{CONCLUSION}

The use of one-stage hypospadias repair at an early age with a low complication rate encourages our current positive outlook for children with this condition. Evidence shows that neourethra grows with the child. Early hypospadias with minimal hospitalisation helps avoid separation anxiety and castration fears. We can now counsel parents confidently that there is an excellent chance of a good cosmetic, functional and emotional result in boys with all degrees of hypospadias.

OIF is indicated in mid and proximal hypospadias with mild-to-moderate chordee. TIF is applicable to children with more proximal hypospadias with severe chordee. Neourethral coverage is important to prevent complications. Transverse island flap of the inner prepuce has provided a reliable technique. The complication rates were more with TIF, every effort should be made to preserve the urethral plate wherever feasible and OIF is a better option if there is a fair urethral plate. Selection of procedure for the type of anatomy is of utmost importance.

\section{REFERENCES}

[1] Horton CE, Devine CJ, Barcat N. Pictorial history of hypospadias repair techniques. In: Horton CE (edr). Plastic and reconstructive surgery of the genital area. Little Brown, Boston 1973:237-48.

[2] Wiener JS, Sutherland RW, Roth DR, et al. Comparison of onlay and tubularized island flaps of inner preputial skin for the repair of proximal hypospadias. J Urol 1997;158(3 Pt 2):1172-4.

[3] Hollowell JG, Keating MA, Snyder HM III, et al. Preservation of the urethral plate in hypospadias repair: extended applications and further experience with the onlay island flap urethroplasty. J Urol 1990;143(1):98-100.

[4] Snodgrass WT, Patterson K, Plaire JC, et al. Histology of the urethral plate: implications of hypospadias repair. J Urol 2000;164(3 Pt 2):988-9.

[5] Duckett JW. Transverse preputial island flap technique for repair of severe hypospadias. Urol Clin North Am 1980;7(2):423-30.

[6] Gittes RF, McLaughlin AP. Injection technique to induce penile erection. J Urology 1974;4(4):473-4.

[7] DiSandro M, Palmer JM. Stricture incidence related to suture material in hypospadias surgery. J Pediatr Surg 1996;31(7):881-4.

[8] Demirbilek S, Kanmaz T, Aydin G, et al. Outcomes of one-stage techniques for proximal hypospadias repair. J Urol 2001;58(2):267-70.

[9] Keating MA, Duckett JW. Recent advances in the repair of hypospadias. Surg Ann 1990;22:405-25.

[10] Desirotte J, Petit R, Nicolas H. Operative experience in hypospadias surgery. Acta Urol Belg 1995;63(4):9-12.

[11] Goepel M, Otto T, Kropfl D, et al. Recent considerations for hypospadias repair: results of 252 operations from 1985 to 1990. Eur Urol 1996;29(1):63-6.

[12] Grobbelaar AO, Laing JH, Harrison DH, et al. Hypospadias repair: the influence of postoperative care and a patient factor on surgical morbidity. Ann Plast Surg 1996;37(6):612-7.

[13] Sorber M, Feitz WF, de Vries JD. Short- and midterm outcome of different types of one-stage hypospadias corrections. Eur Urol 1997;32(4):475-9.

[14] Monfort G, Jean P, Lacoste M. Correction des hypospadias posterieursenun temp par lambeaupedicule transversal (intervention de duckett). Chir Pediatr 1983;24:71-4.

[15] Jayanthi VR, McLorie GA, Khoury AE, et al. Functional characteristics of the reconstructed neourethra after island flap urethroplasty. J Urol 1995;153(5):1657-9.

[16] Dewan PA, Dinneen MD, Winkle D, et al. Hypospadias: duckett pedicle tube urethroplasty. Eur Urol 1991;20(1):39-42.

[17] Baskin LS, Duckett JW, Ueoka K, et al. Changing concepts of hypospadias curvature lead to more onlay island flap procedures. J Urol 1994;151(1):191-6. 
[18] Castanon M, Munoz E, Carrasco R, et al. Treatment of proximal hypospadias with a tubularized island flap urethroplasty and the onlay technique: a comparative study. J Pediatr Surg 2000;35(10):1453-5.

[19] Hayashi Y, Sasaki S, Kojima Y, et al. One-stage repair of moderately severe hypospadias using a transverse preputial tubularized island flap. Int $\mathrm{J}$ Urol 2001;8(4):165-70.
[20] Biosca PC, Osorio MJA, Farina AD, et al. Treatment of proximal hypospadias: the onlay technique. Cir Pediatr 2004;17(1):25-7.

[21] Gearhart JP, Borland RN. Onlay island flap urethroplasty: variation on a theme. J Urol 1992;148(5):1507-9. 